\title{
Occurrence of Salmonella, Listeria monocytogenes, and enterotoxigenic Staphylococcus in goat milk from small and medium-sized farms located in Minas Gerais State, Brazil
}

\author{
V. Q. Cavicchioli, ${ }^{*}$ T. M. Scatamburlo, ${ }^{*}$ A. K. Yamazi, ${ }^{*}$ F. A. Pieri, ${ }^{\dagger} \dagger$ and L. A. Nero*1 \\ *Departamento de Veterinária, Universidade Federal de Viçosa, 36570900 Viçosa, MG, Brazil \\ †Departamento de Ciências Básicas da Saúde, Universidade Federal de Juiz de Fora-Campus Avançado Governador Valadares, 35020220 , \\ Governador Valadares, MG, Brazil
}

\begin{abstract}
Consumption of goat milk has been increasing due to its nutritional characteristics and health benefits. Therefore, assessment of the presence of foodborne pathogens in this product is critical to ensure its safety to consumers. The present study aimed to identify common foodborne pathogens in raw goat milk. Fifty-three samples of raw goat milk from 11 farms were collected and cultured for the presence of Salmonella spp. and Listeria monocytogenes, as well as for enumeration and isolation of coagulase-positive and coagulase-negative Staphylococcus (CPS and CNS, respectively). All samples tested negative for Salmonella spp. and L. monocytogenes. The CPS counts in raw goat milk samples were predominantly less than $2 \log \mathrm{cfu} / \mathrm{mL}(\mathrm{n}=39)$, and CNS counts were predominantly higher than $3 \log \mathrm{cfu} /$ $\mathrm{mL}(\mathrm{n}=42)$. Based on Staphylococcus counts, 51 isolates were selected $(\mathrm{CPS}=26 ; \mathrm{CNS}=25)$ and tested by PCR for the presence of classic enterotoxin-encoding genes (sea, seb, sec, sed, and see). Only 3 isolates (CPS = 2 , CNS $=1$ ) were negative for all enterotoxin-encoding genes tested, and the genotype sec and see was the most frequent $(\mathrm{n}=16)$, followed by sea, sec, and see $(\mathrm{n}=13)$ and $\sec (\mathrm{n}=13)$; sed was not detected in any isolate. The frequencies of enterotoxin-encoding genes for CPS and CNS were similar, demonstrating the equivalence of both groups in harboring these virulent markers. These results suggest that Salmonella and L. monocytogenes are not frequent contaminants of raw goat milk, but that Staphylococcus spp. that are capable of producing enterotoxins are prevalent; therefore, consumers of raw goat milk and products made from raw milk are at risk. Key words: goat milk, foodborne pathogens, coagulase-positive Staphylococcus, coagulase-negative Staphylococcus, enterotoxin-encoding genes
\end{abstract}

Received April 22, 2015

Accepted June 26, 2015.

${ }^{1}$ Corresponding author: nero@ufv.br

\section{INTRODUCTION}

Goat milk production in Brazil has increased in recent years as a result of government programs designed to encourage this activity (Oliveira et al., 2011). According to the FAO database, Brazil produced a total of 111,500 $t$ of goat milk in 1996, and 153,000 $t$ in 2013, representing an increase of $37 \%$ in this period (FAOSTAT, 2013). Most of the national goat herd is concentrated in the northeastern Brazilian states (Oliveira et al., 2011). In this region, the farms are mostly traditional, family farms, in contrast with the large-scale goat farms located in the southeastern states, especially in Minas Gerais state, where the production is more structured.

Goat milk has been attracting consumer interest mainly due to its differentiated nutritional properties when compared with cow milk (Haenlein, 2004; Park, 2007). The technological potential of goat milk has been widely explored for developing distinctive products, especially cheeses (Ribeiro and Ribeiro, 2010). These products have high added value due to their particular sensory features and perception as a healthy food among consumers (Silanikove et al., 2010; Medina et al., 2011; Garcia et al., 2014). Several types of cheeses are made from raw goat milk, which can be considered a concern to public health. Some studies have shown goat milk and goat milk products to be potential sources by pathogens, such as Salmonella spp. and Listeria monocytogenes, as well as enterotoxins produced by Staphylococcus spp. (Silanikove et al., 2010; Rola et al., 2014). In this regard, guaranteeing adequate sanitary status of the herd and the environment, as well as efficient control during all stages of production, is required to ensure the quality and safety of these products.

Data regarding the microbiological safety of goat milk produced in Brazil are relatively limited. Therefore, the present work aimed to evaluate the microbiological safety of raw goat milk produced in a specific region of Brazil, located in Minas Gerais state, considering the most common foodborne pathogens associated with 
this product: L. monocytogenes, Salmonella spp., and enterotoxigenic Staphylococcus.

\section{MATERIALS AND METHODS}

\section{Sample Collection}

A total of 53 raw goat milk samples were collected from 11 farms in the region of Viçosa, Minas Gerais, Brazil. At least 2 samples were collected from each farm. The farms were selected based primarily on permanent practice of dairy goat activity, as well as ease of access, compliance of producers, and availability for sampling. All farms evaluated were characterized by small to medium properties (maximum of 100 lactating goats, usually Saanen, with daily production varying from 100 to $500 \mathrm{~L}$ ), and an intensive production system with hand milking in most of farms.

Sterile utensils were used during sampling, and the samples were transported under refrigeration until analysis. Aliquots from each sample were homogenized and diluted 10-fold by using $0.85 \% \mathrm{NaCl}$ (wt/vol). Goat milk samples were subjected to microbiological analysis to evaluate the presence of $L$. monocytogenes and Salmonella spp. and for enumeration of Staphylococcus spp.

\section{Microbiological Analysis}

The method of Wehr and Frank (2004) was used for the detection of L. monocytogenes. Aliquots of $25 \mathrm{~mL}$ of samples were added to $225 \mathrm{~mL}$ of Listeria enrichment broth (Oxoid Ltd., Basingstoke, UK) and incubated at $30^{\circ} \mathrm{C}$ for $24 \mathrm{~h}$. Cultures were streaked on Palcam agar (Oxoid) and Oxford agar (Oxoid) and incubated at $37^{\circ} \mathrm{C}$ for $24 \mathrm{~h}$. Typical colonies were streaked on trypticase soy agar (Oxoid) at $35^{\circ} \mathrm{C}$ for $24 \mathrm{~h}$ and isolated colonies were cultivated for biochemical identification, according to ISO 11290-1 (ISO, 1996).

Salmonella spp. were cultured according to the methods of Wehr and Frank (2004). Aliquots of $25 \mathrm{~mL}$ of samples were transferred to sterile sampling bags containing $225 \mathrm{~mL}$ of lactose broth (Oxoid) and incubated at $37^{\circ} \mathrm{C}$ for $20 \mathrm{~h}$. Aliquots from obtained cultures were transferred to Rappaport-Vassiliadis broth (Oxoid) and tetrathionate broth (Oxoid) with incubation at $42^{\circ} \mathrm{C}$ for $24 \mathrm{~h}$ and $37^{\circ} \mathrm{C}$ for $24 \mathrm{~h}$, respectively. Obtained cultures were streaked in xylose lysine deoxycholate agar (Oxoid) and mannitol lysine crystal violet brilliant green agar (Oxoid) and incubated at $37^{\circ} \mathrm{C}$ for 24 to 48 h. Typical colonies of Salmonella spp. were transferred to triple sugar iron agar (Oxoid) and lysine iron agar (Oxoid), incubated at $35^{\circ} \mathrm{C}$ for $24 \mathrm{~h}$, and subsequently submitted to serological reactions by using flagellar
$(\mathrm{H})$ and somatic $(\mathrm{O})$ polyvalent antiserum (Probac do Brasil, São Paulo, Brazil).

Staphylococcus spp. was enumerated according to ISO 6888-2 (ISO, 1999). Aliquots of $1 \mathrm{~mL}$ from selected dilutions were pour plated in duplicate in rabbit plasma fibrinogen agar (bioMérieux, Marcy l'Etoile, France) and incubated at $37^{\circ} \mathrm{C}$ for 24 to $48 \mathrm{~h}$. Colonies with fibrin coagulation halos were enumerated as coagulase-positive Staphylococcus (CPS), and colonies without the halo were enumerated as CNS. Both CPS and CNS colonies were randomly selected from plates obtained from different samples and farms and subjected to phenotypical identification by Gram staining and catalase production. Staphylococcus spp. isolates were preliminarily identified as gram-positive cocci and catalase positive, according to ISO (1999). Staphylococcus spp. counts were expressed as colony-forming units per milliliter.

\section{Detection of Enterotoxin-Encoding Genes in CPS and CNS Isolates}

Staphylococcus spp. isolates $(\mathrm{n}=51)$ were subjected to PCR to verify the presence of genes related to production of classic enterotoxin (sea, seb, sec, sed, and see). Single colonies from each isolate were transferred to brain heart infusion broth (Oxoid) and incubated overnight at $37^{\circ} \mathrm{C}$. Aliquots were subjected to DNA extraction using the DNA Purification Kit Wizard Genomic (Promega Corporation, Madison, WI). Then, DNA quantity and quality were assessed by horizontal electrophoresis using a mix of $2 \mu \mathrm{L}$ of obtained DNA, $2 \mu \mathrm{L}$ of blue/orange loading dye $6 \times$ (Promega Corp.), and $1 \mu \mathrm{L}$ of GelRed $20 \times($ Biotium Inc., Hayward, CA). The DNA preparations were kept at $-25^{\circ} \mathrm{C}$ until PCR amplification.

The presence of enterotoxin-encoding genes was determined either by multiplex (seb and sec) or simplex (sea, sed, and see) PCR reactions. Multiplex PCR was performed in a final volume reaction of $25 \mu \mathrm{L}$, containing $12.5 \mu \mathrm{L}$ of GoTaq Green Master Mix $2 \times$ (Promega Corp.), $8.5 \mu \mathrm{L}$ of nuclease-free water, $200 \mathrm{n} M$ of each primer, and $2 \mu \mathrm{L}$ of DNA template. For sea, sed, and see detection, $400 \mathrm{mM}$ of each primer was incorporated into a $25-\mu \mathrm{L}$ volume reaction. Primer sequences and PCR amplification conditions used in these reactions were previously described (Mehrotra et al., 2000; Rosec and Gigaud, 2002). The PCR products were separated by horizontal electrophoresis on $1.5 \%$ (wt/vol) agarose gels in $0.5 \times$ Tris-borate-EDTA buffer alongside $100 \mathrm{bp}$ of DNA Ladder (Promega Corp.), revealed in a GelRed $3 \times$ solution, and visualized under UV light. Staphylococcus aureus reference strains FRI 100 (sea gene), ATCC 14458 ( seb gene), ATCC 19095 ( sec gene), FRI 
472 (sed gene), and FRI 326 (see gene) were used as positive controls in PCR reactions; DNA from these strains was extracted as previously described.

\section{RESULTS AND DISCUSSION}

Drinking raw goat milk and consuming cheese made from it have been associated with salmonellosis outbreaks in humans. In a large outbreak in France in 1993, consumption of cheese from unpasteurized goat milk caused a huge number of consumers to be infected with Salmonella Paratyphi B; the bacteria was isolated from milk at the processing plant on 2 of 5 occasions and was found in the milk from only 1 of 40 farms that supplied the plant (De Buyser et al., 2001). In the same way, L. monocytogenes can be considered a grave threat to dairy industry. This species causes abortion and perinatal septicemia in pregnant women and meningitis in the elderly and immunocompromised patients, and it can also produce clinical and subclinical mastitis in ruminant animals (Ryser, 2011). Unlike many other bacterial foodborne pathogens, L. monocytogenes can grow in milk at refrigeration temperatures and reach potentially infectious levels in certain high-moisture and surface-ripened cheeses (Melo et al., 2015).

Salmonella spp. and L. monocytogenes were not detected in any of the tested samples, suggesting that both pathogens are uncommon in goat milk in the farms sampled. Data concerning these pathogens in goat milk in Brazil are scarce; however, some studies have showed the absence or low frequencies of Salmonella and $L$. monocytogenes in goat milk around the world (Foschino et al., 2002; Morgan et al., 2003; Oliveira et al., 2011). This can occur due to the presence of antimicrobial compounds, such as lactic acid and bacteriocins, produced by lactic acid bacteria, commonly present as part of the autochthonous microbiota of goat milk (Perin and Nero, 2014). However, the obtained results for Salmonella and L. monocytogenes must be interpreted with care, as different factors can interfere in the isolation of these pathogens (Nero et al., 2009). Important public health measures to control foodborne pathogens in milk and prevent outbreaks are pasteurization, avoiding the consumption of raw milk, restricting postpasteurization contamination, and ensuring good manufacturing practices for producing cheeses (Ryser, 2011).

Staphylococcus spp. were detected in all samples ( $\mathrm{n}=$ 53) but concentrations were highly variable (Table 1). Concentration of Staphylococcus spp. in raw goat milk samples was different between CPS and CNS. The CPS counts were predominantly lower than $2 \log \mathrm{cfu} / \mathrm{mL}$ (n $=39$ ), and CNS counts were predominantly higher than $3 \log \mathrm{cfu} / \mathrm{mL}(\mathrm{n}=42)$, indicating that the CNS can be a significant contaminant of goat milk. The presence of
Table 1. Concentrations (cfu/mL) of coagulase-positive Staphylococcus (CPS) and CNS in goat milk samples obtained in the region of Viçosa, Minas Gerais, Brazil

\begin{tabular}{lrc}
\hline Concentration & CPS & CNS \\
\hline$<10 \mathrm{cfu} / \mathrm{mL}$ & 35 & 2 \\
10 to $99 \mathrm{cfu} / \mathrm{mL}$ & 4 & 0 \\
100 to $999 \mathrm{cfu} / \mathrm{mL}$ & 11 & 9 \\
1,000 to $9,999 \mathrm{cfu} / \mathrm{mL}$ & 2 & 35 \\
$\geq 10,000 \mathrm{cfu} / \mathrm{mL}$ & 1 & 7 \\
Total & 53 & 53 \\
\hline
\end{tabular}

Staphylococcus spp. in milk is generally due to a lack of proper hygienic measures, inappropriate manipulation during milking and milk storage, and animals affected by mastitis (Le Loir et al., 2003). In particular, CNS has been reported as a common etiological agent of subclinical mastitis in goats (Silva et al., 2004; Contreras et al., 2007), suggesting that the presence of this group in the herds evaluated may be linked to the occurrence of this disease.

The presence of Staphylococcus spp. samples is a concern because of their ability to produce enterotoxins. At least 20 serologically distinct staphylococcal enterotoxins (SE) are produced by Staphylococcus strains, which could be responsible for food poisoning (Argudín et al., 2010). Traditionally, classic antigenic SE types have been recognized: $\mathrm{SEA}, \mathrm{SEB}, \mathrm{SEC}_{1}, \mathrm{SEC}_{2}, \mathrm{SEC}_{3}, \mathrm{SED}$, and SEE. Symptoms, such as nausea, emesis, abdominal cramps, and diarrhea, develop 2 to $4 \mathrm{~h}$ after food intake, and their severity depends on the amount of ingested toxin and individual health condition (Le Loir et al., 2003; Cremonesi et al., 2007). For a long time, SE production was associated only with CPS, especially $S$. aureus; however, the potential of producing SE CNS is already known (Podkowik et al., 2013). Goat milk and dairy products are good substrates for Staphylococcus spp. growth and a known source of staphylococcal intoxication (De Buyser et al., 2001). Considering the fact that some types of refined cheeses are produced using raw goat milk, the presence of Staphylococcus spp. is a major concern. Pasteurization is recommended to reduce the risk of contamination, but even though this process inactivates Staphylococcus cells, SE are thermostable and remain active in the product. Once the enterotoxins are produced, they generally retain their biological activity even after heat treatment (Le Loir et al., 2003).

Both CPS $(\mathrm{n}=26)$ and CNS $(\mathrm{n}=25)$ were randomly selected from plates and samples and subjected to molecular characterization. The 51 isolates were tested by PCR for the presence of classic enterotoxin-encoding genes (sea, seb, sec, sed, and see), and results are shown in Table 2. Among CPS and CNS, the presence of enterotoxin genes was observed in 25 and 23 isolates, 
respectively, for one or more tested genes. Nine combinations of results were observed, and only 3 isolates (5.9\%) were negative for each of the 5 genes. The sec gene was detected in higher frequency and found singly in 13 isolates $(25.5 \%)$. The frequency of genotypes containing classic SE genes was higher when simultaneously observing the occurrence of sec and see genes (16 isolates, $31.3 \%$ ), as well as sea, sec, and see (13 isolates, $25.5 \%$ ). The sed gene was not present in any of the isolates. The present study corroborates previous findings that reported sec as the gene with higher frequency among classic enterotoxin genes in Staphylococcus spp. from goat milk (Scherrer et al., 2004; Loncarevic et al., 2005). Reports indicate that the frequencies of such genes can reach from 55.6 (Lyra et al., 2013) to $86 \%$ (Silva et al., 2005) in goat milk samples. The gene sec was also reported as the most frequent $(24.1 \%)$ in $S$. aureus from sheep milk and dairy products (Maslankova et al., 2009). A study involving goat and cow raw milk cheeses showed that sed (65.5\%) and sea $(51.7 \%)$ were the most common classic enterotoxin-encoding genes in Staphylococcus spp. from cow milk cheese, whereas goat staphylococci harbored mainly sec $(97.3 \%$; Cremonesi et al., 2007). Further studies are still required to evaluate expression of the detected enterotoxin genes. Nonetheless, the high numbers of CNS and the detection of enterotoxigenic genes in such strains reinforce the need to establish regulatory standards for total Staphylococcus spp. counts in goat milk.

Brazilian laws that regulate the production of goat and cow milk do not include pathogen analysis in the raw milk (Brasil, 2000, 2011). Even for ready-to-eat dairy products, the official safety monitoring includes only Salmonella spp., L. monocytogenes, and CPS (Brasil, 2001). In Europe, regarding Staphylococcus spp., legislation requires enumeration only for CPS and enterotoxin research in milk and dairy products (EC, 2003). As both CPS and CNS have the ability to produce enterotoxins, especially those enterotoxins that are heat stable, and they may be present in food even when

Table 2. Genotypes defined according to the presence of staphylococcal enterotoxin genes (sea, seb, sec, sed, and see) in coagulase-positive Staphylococcus (CPS) and CNS isolates obtained from goat milk

\begin{tabular}{lccc}
\hline Genotype & CPS & CNS & Total \\
\hline sec, see & 8 & 8 & 16 \\
sea, sec, see & 7 & 6 & 13 \\
sec & 8 & 5 & 13 \\
sea, sec & 1 & 1 & 2 \\
sea, seb, sec & 1 & 0 & 1 \\
seb, sec, see & 0 & 1 & 1 \\
seb, sec & 0 & 1 & 1 \\
see & 0 & 1 & 1 \\
None & 2 & 1 & 3 \\
Total & 27 & 24 & 51 \\
\hline
\end{tabular}

Staphylococcus spp. is absent, an updated legislation needs to be considered. A diagnostic approach applied to dairy products, particularly those derived from raw milk, must consider detection of enterotoxins and the screening of enterotoxin encoding genes in Staphylococcus spp. isolates, to ensure consumer safety.

The results obtained in our study indicate that $L$. monocytogenes and Salmonella spp. are not common pathogens of goat milk in the studied area. However, the presence of Staphylococcus spp. at different contamination levels was related to the fact that most of the isolates were positive for at least one enterotoxin gene and is cause for concern. Furthermore, CNS should not be ignored due to its enterotoxigenic ability and additional studies are required to clarify its pathogenic potential.

\section{ACKNOWLEDGMENTS}

The authors thank Brazilian financial agencies: CAPES (Coordenação de Aperfeiçoamento de Pessoal de Nível Superior), CNPq (Conselho Nacional de Pesquisa Científica), and FAPEMIG (Fundação de Amparo à Pesquisa do Estado de Minas Gerais).

\section{REFERENCES}

Argudín, M. Á., M. C. Mendoza, and M. R. Rodicio. 2010. Food poisoning and Staphylococcus aureus enterotoxins. Toxins (Basel) $2: 1751-1773$.

Brasil. 2000. Instrução Normativa 37-Aprova o Regulamento Técnico de Identidade e Qualidade de Leite de Cabra. Diário Oficial da União, 08 de novembro de 2000 ed. MAPA, ed. Brasília, DF, Brazil.

Brasil. 2001. Resolução RDC 12-Aprova o Regulamento Técnico Sobre Padrões Microbiológicos Para Alimentos. Diário Oficial da União. Brasil, Brasília, DF, Brazil.

Brasil. 2011. Instrução Normativa 62-Aprova o Regulamento Técnico de Produção, Identidade e Qualidade do Leite tipo A, o Regulamento Técnico de Identidade e Qualidade de Leite Cru Refrigerado, o Regulamento Técnico de Identidade e Qualidade de Leite Pasteurizado e o Regulamento Técnico da Coleta de Leite Cru Refrigerado e seu Transporte a Granel. Diário Oficial da União. Brasil, Brasília, DF, Brazil.

Contreras, A., D. Sierra, A. Sánchez, J. C. Corrales, J. C. Marco, M. J. Paape, and C. Gonzalo. 2007. Mastitis in small ruminants. Small Rumin. Res. 68:145-153.

Cremonesi, P., G. Perez, G. Pisoni, P. Moroni, S. Morandi, M. Luzzana, M. Brasca, and B. Castiglioni. 2007. Detection of enterotoxigenic Staphylococcus aureus isolates in raw milk cheese. Lett. Appl. Microbiol. 45:586-591.

De Buyser, M. L., B. Dufour, M. Maire, and V. Lafarge. 2001. Implication of milk and milk products in food-borne diseases in France and in different industrialised countries. Int. J. Food Microbiol. 67:1-17.

European Commission (EC). 2003. Cheese consumption (availability) for 2002 in the European Union and in third countries. Page 73 in Staphylococcal Enterotoxins in Milk Products, Particularly Cheeses. European Commission, Brussels, Belgium.

FAOSTAT. 2013. Food and Agriculture Organization of the United Nations. Accessed Mar. 17, 2015. http://faostat.fao.org.

Foschino, R., A. Invernizzi, R. Barucco, and K. Stradiotto. 2002. Microbial composition, including the incidence of pathogens, of goat 
milk from the Bergamo region of Italy during a lactation year. J. Dairy Res. 69:213-225.

Garcia, V., S. Rovira, K. Boutoial, and M. B. Lopez. 2014. Improvements in goat milk quality: A review. Small Rumin. Res. 121:51-57.

Haenlein, G. F. W. 2004. Goat milk in human nutrition. Small Rumin. Res. 51:155-163.

ISO. 1996. ISO 11290-1-Microbiology of food and animal feeding stuffs-Horizontal method for the detection and enumeration of Listeria monocytogenes - Part 1: Detection method. Internation Organization for Standardization (ISO), Geneva, Switzerland.

ISO. 1999. ISO 6888-2. Microbiology of food and animal feeding stuffs - Horizontal method for the enumeration of coagulase positive staphylococci (S. aureus and other species): Part 1. Technique using rabbit plasma fibrinogen agar medium. International Organization of Standardization (ISO), Geneva, Switzerland.

Le Loir, Y., F. Baron, and M. Gaultier. 2003. Staphylococcus aureus and food poisoning. Genet. Mol. Res. 2:63-76.

Loncarevic, S., H. J. Jorgensen, A. Lovseth, T. Mathisen, and L. M. Rorvik. 2005. Diversity of Staphylococcus aureus enterotoxin types within single samples of raw milk and raw milk products. J. Appl. Microbiol. 98:344-350.

Lyra, D. G., F. G. C. Sousa, M. F. Borges, P. E. N. Givisiez, R. C. R. E. Queiroga, E. L. Souza, W. A. Gebreyes, and C. J. B. Oliveira. 2013. Enterotoxin-encoding genes in Staphylococcus spp. from bulk goat milk. Foodborne Pathog. Dis. 10:126-130.

Maslankova, J., I. Pilipcincova, and L. Tkacikova. 2009. Pheno- and genotyping of Staphylococcus aureus isolates of sheep origin. Acta Vet. Brno 78:345-352.

Medina, R. B., R. Oliszewski, M. C. A. Mukdsi, C. P. Van Nieuwenhove, and S. N. Gonzalez. 2011. Sheep and goat's dairy products from South America: Microbiota and its metabolic activity. Small Rumin. Res. 101:84-91.

Mehrotra, M., G. Wang, and W. M. Johnson. 2000. Multiplex PCR for detection of genes for Staphylococcus aureus enterotoxins. J. Clin. Microbiol. 38:1032-1035.

Melo, J., P. W. Andrew, and M. L. Faleiro. 2015. Listeria monocytogenes in cheese and the dairy environment remains a food safety challenge: The role of stress responses. Food Res. Int. 67:75-90.

Morgan, F., T. Massouras, M. Barbosa, L. Roseiro, F. Ravasco, I. Kandarakis, V. Bonnin, M. Fistakoris, E. Anifantakis, G. Jaubert, and K. Raynal-Ljutovac. 2003. Characteristics of goat milk collected from small and medium enterprises in Greece, Portugal and France. Small Rumin. Res. 47:39-49.

Nero, L. A., M. R. de Mattos, M. A. F. Barros, V. Beloti, and B. D. G. M. Franco. 2009. Interference of raw milk autochthonous microbiota on the performance of conventional methodologies for Listeria monocytogenes and Salmonella spp. detection. Microbiol. Res. 164:529-535.

Oliveira, C. J. B., E. R. Hisrich, J. F. P. Moura, P. E. N. Givisiez, R. G. Costa, and W. A. Gebreyes. 2011. On farm risk factors associated with goat milk quality in Northeast Brazil. Small Rumin. Res. 98:64-69.

Park, Y. W. 2007. Rheological characteristics of goat and sheep milk. Small Rumin. Res. 68:73-87.

Perin, L. M., and L. A. Nero. 2014. Antagonistic lactic acid bacteria isolated from goat milk and identification of a novel nisin variant Lactococcus lactis. BMC Microbiol. 14:36.

Podkowik, M., J. Y. Park, K. S. Seo, J. Bystroń, and J. Bania. 2013. Enterotoxigenic potential of coagulase-negative staphylococci. Int. J. Food Microbiol. 163:34-40.

Ribeiro, A. C., and S. D. A. Ribeiro. 2010. Specialty products made from goat milk. Small Rumin. Res. 89:225-233.

Rola, J. G., M. Sosnowski, M. Ostrowska, and J. Osek. 2014. Prevalence and antimicrobial resistance of coagulase-positive staphylococci isolated from raw goat milk. Small Rumin. Res. 123:124-128.

Rosec, J. P., and O. Gigaud. 2002. Staphylococcal enterotoxin genes of classical and new types detected by PCR in France. Int. J. Food Microbiol. 77:61-70.

Ryser, E. T. 2011. Pathogens in milk: Listeria monocytogenes. Pages 1650-1655 in Encyclopedia of Dairy Sciences. 2 ed. J. W. Fuqyay, ed. Academic Press, London, UK.

Scherrer, D., S. Corti, J. E. Muehlherr, C. Zweifel, and R. Stephan 2004. Phenotypic and genotypic characteristics of Staphylococcus aureus isolates from raw bulk-tank milk samples of goats and sheep. Vet. Microbiol. 101:101-107.

Silanikove, N., G. Leitner, U. Merin, and C. G. Prosser. 2010. Recent advances in exploiting goat's milk: Quality, safety and production aspects. Small Rumin. Res. 89:110-124.

da Silva, E. R., L. S. Carmo, and N. Silva. 2005. Detection of the enterotoxins A, B, and C genes in Staphylococcus aureus from goat and bovine mastitis in Brazilian dairy herds. Vet. Microbiol. 106:103-107.

Silva, E. R., A. P. Siqueira, J. C. D. Martins, W. P. B. Ferreira, and N. Silva. 2004. Identification and in vitro antimicrobial susceptibility of Staphylococcus species isolated from goat mastitis in the northeast of Brazil. Small Rumin. Res. 55:45-49.

Wehr, H. M., and J. F. Frank. 2004. Standard Methods for the Examination of Dairy Products. 17 ed. American Public Health Association, Washington, DC. 